\title{
Varied Thrush at Regina
}

\section{by Margaret Belcher, Regina}

The Varied Thrush (Ixoreus naevius) appears as a hypothetical species for Saskatchewan in the fourth edition of the Field Check-List of Saskatchewan Birds (1959). The species is further treated as hypothetical in the Birds of Regina (1961) where I reported an observation of a single bird which was clearly, but only briefly, seen and which I could not locate again for other observers to check. Additions to the check-list of Saskatchewan birds (Nero and Houston, 1963) do not include the Varied Thrush.

The Varied Thrush has only rarely been reported in Saskatchewan. The Blue Jay (7(4):13) tells of one banded at Burnham, September 27, 1949, by Arthur Ward. The first Regina record I have is the one reported in the Birds of Regina-one with an indistinct breast band, presumably an immature bird, seen in Regina on September 9, 1958. This bird was seen in the high branch of a deciduous tree, and observed well for a few minutes before it flew. I described it at the time in my notes as having a "tawny breast (almost scaly in appearance-but not streaked or spotted), wings with tawny marks or bars. Most conspicuous was a light stripe over eye and continuing down head to nape, otherwise top of head was olive (stripe as conspicuous as that of waterthrush). Bill long, not very heavy." At the same time I sketched a picture of the head, showing the characteristic stripe.

Since the publication of this record, two further Regina observations have been reported to me. On September 30,1961 , one was seen in a hedge by Elsie Cheeseman, and the orange eyestripe and black bar against the reddish chest were noted as reported to Herb and Ruth Tempel; on May 22, 1962, Herb Tempel saw one in shrubbery in the Legislative Grounds.

Finally, an altogether excellent view of a Varied Thrush rewarded the endof-the-season enthusiasm of a small party of Regina bird watchers on October 24,1964 . We were driving past the wooded lawns of the Legislative Grounds in mid-afternoon (about 3:30 p.m. CST) when a bird on the ground, moving about like a Robin, caught my attention because its breast was marked quite unlike a Robin's. The dark necklace across the coloured breast and the stripe over the eye were the first and most conspicuous features noted as I flung the car door open and jumped out, calling upon the others-Lucy Murray, Christine MacDonald and Charlotte Boissonnaultto come and look at the bird with me. Look hard, I said, it's a Varied Thrush!

With binoculars we were able to watch the bird for some minutes and at close range, as it moved first toward us and then deliberately across the lawn down to the water's edge. We carefully established the following features-bright tawny throat, breast, eye stripe and wing markings, with a slate-gray necklace (not black) scooped across its neck, the colour of the necklace blending with the dark gray back. The bird had light-coloured legs, and in addition to the tawny bars on its wings some flecks of white which seemed to edge feathers of the wingtips or tail. We did not see the bird in flight at close enough range to note the details of this pattern. After this detailed observation, Miss Murray went back to the car to get Peterson's Field guide to the western birds, and we could see our birds faithfully pictured there. There could be absolutely no doubt that the bird we were observing so clearly at a distance of no more than 20 yards was a Varied Thrush.

Seeing the bird in Regina prompted me to recall that the last time I had seen a Varied Thrush was on May 31, 1962 , in Yellowstone National Park when on a plant collecting trip with Maureen Rever. I referred casually to the Varied Thrush seen on Mt. Washburn in an article for the Blue Jay (20:149), but did not realize then or subsequently that this species is described by the A.O.U. Check-list (1957) as "accidental" in Wyoming (Yellowstone National Park). Having seen the Varied Thrush in similar country at Banff (summer, 1954), it did not strike me as unusual to find one on our tramp along a road up Mt. Washburn.

The A.O.U. Check-list defines the status of the Varied Thrush as "casual" in southern Alberta (Belvedere, Edburg, Sullivan Lake, Rosebud) 
and central Montana (Missoula, Bozeman, Fort Custer). Salt and Wilk (1958) describe it as breeding in Alberta in the Rocky Mountains from the international boundary to north of Jasper, appearing on the prairies "only as an accidental straggler well off its usual migration route." It is noted that in fall it may not leave the Banff area until early October, and that it is during migration periods that Varied Thrushes are occasionally seen east of their usual mountain haunts. Bent (1949) gives some late dates of fall departure that compare interestingly with our recent Regina record: "Alberta-Edberg, October 10. Montana-Fortine, October 24. IdahoPriest River, November 8."

The Varied Thrush migration is a matter of a downward, as well as a southward, movement-which further complicates the pattern. It moves for the winter from the mountains to the lower valleys. Its appearance in Regina reminds one of the Townsend's Solitaire, another species which appears in migration far east of its breeding range in the mountain forests, and for which there are a number of Regina records.

Bent refers to migrant Varied Thrushes found east of their normal range being "usually in company with robins"; we noted on the afternoon on which we saw the thrush a little flock of Robins in the Legislative Grounds where the local robins had been conspicuously scarce for some days.

\section{LITERATURE CITED}

American Ornithologists' Unlon. 1957. Checklist of North American birds. Fifth edition. Baltimore, Md. 691 pp.

Belcher, M. 1961. Birds of Regina, Special Publ. No. 3, Saskatchewan Natural History Society, Regina, Sask. 76 pp.

1962. Getting to know our less common birds. The Blue Jay, 20:146-150, December, 1962.

Bent, A. C. 1949. Life histories of North American thrushes, kinglets and their allies. Smithsonian Institution, Washington.

Houston, [C. $]$ S., F. G. Bard, and R. W. Nero. 1959. Field check-list of Saskatchewan birds. Fourth edition, revised. Sask. Museum of Natural History, Regina, Sask.

Nero, R. W., and C. S. Houston. 1963. Additions to the check-list of Saskatchewan birds. The Blue Jay, 21:132-133.

Salt, W. Ray, and A. L. Wilk. 1958. The birds of Alberta. Queen's Printer, Edmonton. 511 pp.

\section{NORTHERN RECORDS FOR CINNAMON TEAL}

by Herb C. Moulding, Regina

On Saturday morning, June 6th accompanied by Bill Hooey and Tom Sterling of Ducks Unlimited, we were inspecting Scentgrass Lake north of Battleford. As we were driving along the road at the west end of the lake, having just crossed the outlet, we observed a male Cinnamon Teal in the road ditch. This same teal was in the same location when we returned from inspecting the lake (which incidentally harbored approximately 1,200 Canvasback, mostly drakes, at the east end of the marsh). The teal was reluctant to fly which would indicate that there could have been a pair in the vicinity.

It is only periodically that Cinnamon Teal are observed in Saskatchewan. How far north these birds have been ohserved is not known, but the above report is being submitted to verify the fact that they were observed fifteen miles north of Battleford in June, 1964.

\section{A TREE-PERCHING SORA}

\section{by John B. Millar,}

Canadian Wildlife Service, Saskatoon

On June 4, 1963, I flushed an adult Sora (Porzana carolina) from a small slough near Swift Current, Saskatchewan. Instead of dropping back into the vegetation in the usual fashion after a short flight, it flew perhaps a hundred feet and landed five feet up in an isolated eight-foot willow tree (Salix sp.) at the water's edge. When I attempted to flush it from the tree the Sora merely hopped from branch to branch to the far side. As I moved around toward the bird it worked its way back through the branches to its former position. This procedure was repeated five or six times before the bird finally left the willow and flew back across the slough. This Sora's behaviour was particularly interesting in that it appeared to be quite at ease among the branches and moved about in the manner of a small fringillid.

Baird, Brewer and Ridgway (In Bent, Life Histories of North American 